\title{
Changes in local climate in the neighbourhood of the Ust-Ilimsk water reservoir
}

\author{
on the Angara, Russia
}

\author{
Tatiana A. Tashlykova \\ Institute of Earth Crust, Siberian Branch of Russian Academy of Sciences, Lermontova Str. 128, Irkutsk, Russia, \\ E-mail address: tta1964@mail.ru
}

\begin{abstract}
The paper presents results of investigations on microclimate over one of the largest artificial water reservoirs in the world Ust-Ilimsk on the Angara in Russia. It is located in the western edge of the Central Siberian Upland in the northern part of Irkutsk Oblast. The area of reservoir at a normal level of water damming (296 m a.s.l.) amounts to $1873 \mathrm{~km}^{2}$, the capacity of stored water $-59,4 \mathrm{~km}^{3}$, and the shoreline length is equal to $2384 \mathrm{~km}$. The evaluation of the influence of the water reservoir on local climate was based on the analysis of data collected over many years measurements of a series of particular elements of the climate and carried out in the direct neighbourhood of the reservoir before (1936-1975) and after its construction in 1977. From the research the results show that the Ust-Ilimsk water reservoir distinctly influences the local climate of adjacent areas. The differences are mostly connected with the increase in total radiation and changes in the radiation balance of the reservoir, and the larger heat capacity of the water mass in comparison to land. As data from meteorological stations indicate, the climate in the neighbourhood of this water reservoir gains many new features and generally becomes milder. The average annual increase in air temperature over the reservoir shores reached $1.3^{\circ} \mathrm{C}$, whereas with in land it was only $0.4^{\circ} \mathrm{C}$. At every meteorological station (inshore and continental), in the summer period and during the whole year as well, the average sum precipitation decreased by $7-14 \%$. In the winter, when polynya exist, the number of days with fogs increases over the reservoir. Fogs in the shore zone of the Ust-Ilimsk reservoir delay the coming of frosts by 1-2 weeks.
\end{abstract}

KEY WORDS: microclimate, water dam, Central Siberian Upland

\section{Introduction}

The creation and functioning of anthropogenic water reservoirs in river valleys can change the local climate in an essential way. Storage (damming up) of large amounts of water in the valley causes significant changes in its relief causing a decrease in relative heights and a change in the shape of the cross-section, while water reservoirs, as new thermal elements of the environment of different physical properties to land, influence meteorological conditions of adjacent areas. The surface, which is influenced by the reservoir, is comparable with the surface of the water table. Significant changes in microclimate are observed in the inshore zone, as the distance from the shoreline increases, the influence of the water body on the local climate decreases.

Size and range of influence of water reservoirs on local climate depend on many factors, such as its area, capacity, development of the shoreline or the direction of the main axis of the reservoir in relation to the prevailing winds. Generally, water reservoirs cause thermal contrasts of air that are milder. But their influence on meteorological conditions is not constant during the whole year and depends on the heat energy supply. Periodic fluctuations of the thermal-humidity regime are connected with the release of considerable amounts of heat by water reservoirs in the cool season and an accumulation of energy in the spring-summer season.

Investigations into the influence of anthropogenic water reservoirs on the local climate have been widely conducted since the mid-1950s. (BORUSHKO, 1965; Viculina \& SELJUK, 1966; CHANGNON, 1966; RODHE, 1968; MARZEC, 1971; LEWIŃSKA, 1974; RASTORGUEV \& ROSHCHINA, 1987; OBRĘBSKASTARKLOWA \& GRZYBOROWSKA, 1995; LOFGREN \& ZHU, 1999; MEIJNINGER \& DE BRUIN, 2000; MAŁECKI, 
2009; MiCZYŃSKI ET AL., 2010; DEGU ET AL., 2011; WANG ET AL., 2012). Considering the wide range of effects on climate differences in the neighbourhood of large water reservoirs these investigations are of special significance. In the given paper results are presented of investigations on microclimate changes over one of the largest artificial water reservoirs in the world - Ust-Ilimsk on the Angara in Russia.

\section{Research method}

This evaluation of the influence of a water reservoir on the local climate was based on analysis of data collected over many years with a series of measurements of particular elements of climate, carried out at stations in the direct neighbourhood of the reservoir, both before and after its construction. Comparisons of the data collected allows a real expression of climatic differences caused by reservoir functioning. Data from the literature were also applied, especially from the study of GUSTOKASHINA \& BALYBINA (2005), who made an attempt to compare air temperatures and precipitation at meteorological stations located directly on the shore zone of the reservoir and away from it in the period before (1936-1975) and after its construction in 1977.

\section{Study area}

The Ust-Ilimsk water reservoir is located in the western edge of the Central Siberian Upland, within the Lena-Angara Plateau, limited by the Kovinski Ridge in the west and the Angara Ridge in the east. This reservoir is located in the northern part of Irkutsk Oblast within the administrative regions of Ust-Ilimsk, Niznieilimsk and the northern part of Bratsk. It is third in order of size of artificial water reservoirs on the Angara (Fig. 1). Heights decrease here from $850 \mathrm{~m}$ a. s. l. in the upper course of the Ilim river to $200 \mathrm{~m}$ a. s. $\mathrm{l}$. at the dam of Ust-Ilimsk Hydroelectric Power Station. In the internal part of the region some elevations reach 800-850 $\mathrm{m}$ a.s.l., it is possible to notice the general terrain inclination towards north-west. The river network of the investigated area is represented by the Angara at the Bratsk-Ust-Ilimsk section, and the Ilim river with tributaries and small rivers flowing into the Angara. The density of the river network in the majority of the area exceeds $1 \mathrm{~km} / \mathrm{km}^{2}$ (ATLAS, 1962, 1997).

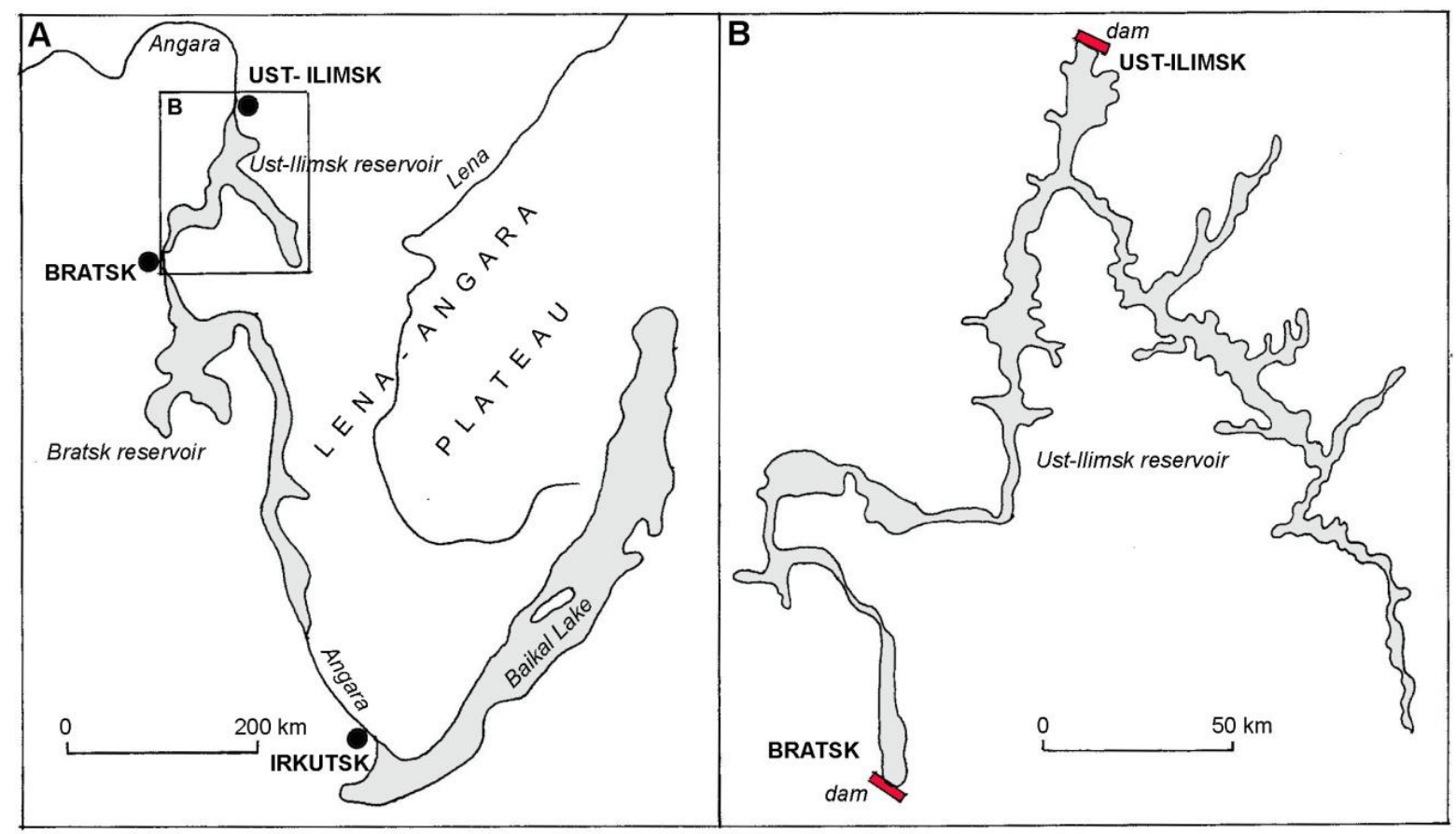

Fig. 1. Location of the Ust-Ilimsk water reservoir

One of main orographic units of this area - the Angara Ridge, in the system of massives (called ranges), runs from the city of Nizhneudinsk towards the north-east, to the central course of the Angara. Rivers - the Angara in upper and middle part of Ust-Ilimsk water reservoir, and the Ilim river in the lower course, cut these ridges, which result in rapids occurring in valley narrowings - from the
Bratsk Hydroelectric Power Station to the city of Ust-Ilimsk. The rapids occur as follows: Padunskiy, Dolgiy, Shamanskiy, Simakhinskiy, in which the average inclination of the river channel amounts to $1.3-5 \%$. In the Angara part of the reservoir, after widening of the dam reservoirs there occurs a narrow area in the form of narrow rocky ravines with steep slopes (more than $20-40^{\circ}$ ). 
The drainage basin of the main tributary of the Angara - the Ilim, in its upper part adjoins to the drainage basin of the Bratsk reservoir, where they have a common watershed. The river flows to the village of Ilimsk in the narrow, deep valley of steep (more than $20^{\circ}$ ), forested slopes. The river channel is full of gravelly bars. In this section the Ilim has a lot of tributaries, of which the most important is the Kochenga (UST-ILIMSKOYE VODOKHRANILISHCHE, 1975). The Ilim river widens 200 $\mathrm{m}$ below the mouth of the Igrim river, and rocky banks are distant from the channel of 3-5 km. This river flows in this area within alluvial terraces and includes a large tributary - the Tuba river. In the neighbourhood of its mouth, at the intersection of ranges of the Angara Ridge the Simakhinskiy rapids occur.

The Ust-Ilimsk water reservoir was built on the Angara tributary of the Ust-Ilim river. Filling of the reservoir with water, coming from floods and the Bratsk reservoir, lasted 2.5 years - from October 1974 to 25.05.1977. The total area of the whole reservoir, at normal damming levels $(296 \mathrm{~m}$ a.s.l.) amounts to $1873 \mathrm{~km}^{2}$, and the capacity of stored water - $59.4 \mathrm{~km}^{3}$. At the given level of damming the reservoir reaches upwards to the Angara - to the dam of Bratsk Hydroelectric Power Station $(304 \mathrm{~km})$, and upwards on the Ilim river to the village of Atalanovo in the Nizhnieilimsk region $(302 \mathrm{~km})$. At lower damming levels the range of the reservoir upwards on both rivers course is respectively lower. The length of flooded valleys of the Angara and Ilim rivers and their tributaries reaches more than $600 \mathrm{~km}$. In the lower flooded sections, 17 tributaries flow into the reservoir and form bays, that are important places for fish spawning. The length of the shoreline of the water body amounts to $2384 \mathrm{~km}$, with a development index of 1.8 (UST-ILIMSKOYE VODOKHRANILISHCHE, 1975; MAGOMEDOV, 2003; OvCHINNIKOV, 2003). The character of the flooded river valleys and the geological structure of that area influence the outline of the reservoir, and it is possible to distinguish the Angara part of the channel and the Ilim part. The morphometric characteristics of the Ust-Ilimsk water reservoir are presented in Tab. 1.

Table 1. Morphometric characteristics of the Ust-Ilimsk water reservoir (after Ovchinnikov, 2003)

\begin{tabular}{|c|c|c|c|c|c|c|c|}
\hline \multirow[t]{2}{*}{ Water areas } & \multirow{2}{*}{$\begin{array}{c}\text { Average } \\
\text { length } \\
{[\mathrm{km}]}\end{array}$} & \multirow{2}{*}{$\begin{array}{l}\text { Maximum } \\
\text { width } \\
{[\mathrm{km}]}\end{array}$} & \multicolumn{2}{|c|}{$\begin{array}{c}\text { Shore length } \\
{[\mathrm{km}]}\end{array}$} & \multirow{2}{*}{$\begin{array}{c}\text { Water } \\
\text { surface area } \\
{\left[\mathrm{km}^{2}\right]}\end{array}$} & \multirow{2}{*}{$\begin{array}{c}\text { Volume of } \\
\text { water } \\
{\left[\mathrm{km}^{3}\right]}\end{array}$} & \multirow{2}{*}{$\begin{array}{c}\text { Average } \\
\text { depth } \\
{[\mathrm{m}]}\end{array}$} \\
\hline & & & Left & Right & & & \\
\hline Angara water area & & & & & & & \\
\hline $\begin{array}{l}\text { 1. Dolgogo Poroga } \\
\text { narrowing }\end{array}$ & 102.0 & 5.4 & 120 & 123 & 198.4 & 2.69 & 15.9 \\
\hline $\begin{array}{l}\text { 2. Sedanowskaya \& } \\
\text { Shamanovskoe } \\
\text { expansions }\end{array}$ & 48.0 & 6.6 & 87 & 78 & 266.8 & 8.56 & 31.2 \\
\hline $\begin{array}{l}\text { 3. Morgudolskoe } \\
\text { narrowing }\end{array}$ & 45.0 & 3.5 & 50 & 62 & 56.4 & 2.48 & 44.0 \\
\hline $\begin{array}{l}\text { 4. Ershovskaya } \\
\text { \& Vorobiev } \\
\text { expansions }\end{array}$ & 50.0 & 10.4 & 124 & 124 & 267.2 & 14.21 & 50.0 \\
\hline $\begin{array}{l}\text { 5. Badaminskoe } \\
\text { narrowing }\end{array}$ & 33.5 & 4.0 & 59 & 46 & 104.0 & 5.19 & 49.9 \\
\hline $\begin{array}{l}\text { 6. Sizovskoye } \\
\text { expansion }\end{array}$ & 28.0 & 7.0 & 107 & 72 & 164.7 & 8.47 & 49.2 \\
\hline 7. Vihorevsky Bay & 30.0 & 1.8 & 69 & 39 & 49.5 & 0.44 & 9.1 \\
\hline Total: & 336.5 & 10.4 & 616 & 544 & 1107.0 & 42.04 & 35.6 \\
\hline \multicolumn{8}{|l|}{ Ilim water area } \\
\hline $\begin{array}{l}\text { 1. Simahinskoe } \\
\text { narrowing }\end{array}$ & 43.0 & 5.3 & 62 & 82 & 173.0 & 5.23 & 30.3 \\
\hline $\begin{array}{l}\text { 2. Nizhne-Ilimskoye } \\
\text { expansion }\end{array}$ & 61.0 & 6.5 & 210 & 189 & 386.0 & 11.30 & 29.3 \\
\hline $\begin{array}{l}\text { 3. Ilimskoye } \\
\text { narrowing }\end{array}$ & 118.0 & 1.3 & 230 & 183 & 79.2 & 1.43 & 17.7 \\
\hline 4. Tubin Bay & 43.0 & 2.5 & 62 & 82 & 78.4 & 2.04 & 26.0 \\
\hline 5. Igirminsky Bay & 42.0 & 2.7 & 64 & 60 & 49.2 & 0.66 & 13.4 \\
\hline Total: & 307.0 & 6.5 & 628 & 596 & 765.8 & 20.66 & 23.3 \\
\hline Total reservoir & 643.5 & 10.4 & 1244 & 1140 & 1872.8 & 62.70 & 29.5 \\
\hline
\end{tabular}


According to the classification of AVAKYAN ET AL. (1987) the Ust-Ilim water body is a valley reservoir which originated by building a dam across the river, it has an azonal character, belongs to the group of deep, with seasonally regulated runoff and slow water exchange, which occurs on average every 0.6 year. This reservoir has originated in an area characterised by varied geology, relief and hydrogeologic-meteorological conditions, therefore its influence on the adjacent areas is also diverse. The intensity of changes in the environment in the neighbourhood of the water body depend to a significant degree on features of the reservoir as a technical-natural object. Changes within the lithosphere, hydrosphere, atmosphere and biosphere, which happened after the reservoir was created and caused transformations of water and land ecosystems.

The geographical location of the Ust-Ilimsk reservoir is in the centre of the Asian continent, in an area of diverse relief and circulation of air masses which decide the climate of its neighbourhood - it is extracontinental with a long, severe and dry winter and a warm and humid summer. In the region of central Angara the most severe climate occurs above the watershed area Angara - Lena (Angara Ridge) and Ust-Ilimsk reservoir (TASHLYKOVA, 2006). One of the main climatic factors is the atmosphere circulation, which because of local physiographic conditions, gives rise to the characteristic features of the climate of that area.

\section{Results}

The influence of the Ust-Ilimsk Reservoir at creating a change in the microclimate has been documented from the results of observations conducted at meteorological stations. Apart from the reservoir with its specific microclimatic conditions, it is possible to distinguish three main zones of influence of the reservoir in adjacent areas: of permanent influence, changeable influence and episodic influence (VODOKHRANILISHCHA, 1986).

\subsection{Air temperature}

Analysis of the data shows, that after the construction of the Ust-Ilimsk water reservoir the average monthly air temperature in the winter period at inshore stations increased by $2.7-3.6^{\circ} \mathrm{C}$ (Fig. 2), and at continental ones - only by $0.8-2^{\circ} \mathrm{C}$. This confirms the commonly known statement of warming - in winter months - due to the influence of the water reservoirs in their adjacent areas. In the summer period at inshore stations the average air temperature was lower by $0.2-0.1^{\circ} \mathrm{C}$, whereas at continental ones it increased by $0.4^{\circ} \mathrm{C}$, or decreased by $0.2^{\circ} \mathrm{C}$. These results also confirm the known cooling influence of reservoirs on the neighbourhood in the summer season. In essence, the average annual increase of air temperatures at reservoir shores reached $1.3^{\circ} \mathrm{C}$, whereas within land - only $0.4^{\circ} \mathrm{C}$. The average absolute minimum temperature in the shore zone increased by $6^{\circ} \mathrm{C}$ on average, whereas at continental stations the increase was only by $2.8^{\circ} \mathrm{C}$. The average absolute maximum air temperature at inshore stations lowered in that period by $0.5^{\circ} \mathrm{C}$, whereas at continental ones - it increased by $0.3^{\circ} \mathrm{C}$ (TASHLYKOVA, 2007). The above-mentioned changes in temperatures show that the cooling influence of the Ust-Ilimsk reservoir on adjacent areas is distinctly weaker than a warming one.

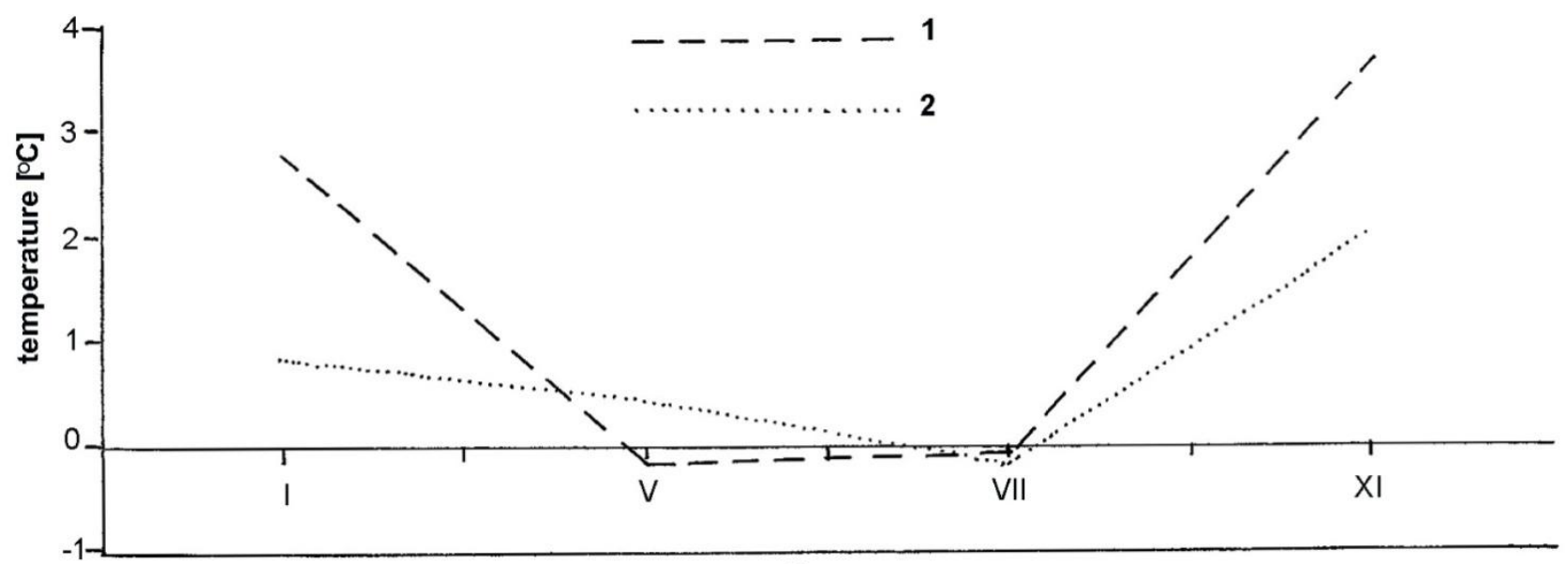

months

Fig. 2. The average monthly changes in air temperature in the region of the Ust-Ilimsk reservoir (after Gustokashina \& Balybina, 2005)

1 - coastal stations; 2 - continental stations 


\subsection{Precipitation}

Many years of lasting observations (VoDoKHRANILISHCHA, 1986) indicate, that changes in the amount of precipitation take place only in periods of the year without ice: in continental parts the amount of precipitation increased slightly, whereas in the inshore area - it decreased a bit. The degree of these changes depends on the direction of the prevailing wind and the character of the shore. In the period of cooling activity of the reservoir the windward shores receive lower amounts of precipitation, whereas in the latter half of summer, and in autumn - under a warming influence - the amount of precipitation increases at windward shores.

According to GUSTOKASHINA \& BALYBINA (2005) (Fig. 3) after the Ust-Ilimsk water reservoir was built the average precipitation sum decreased by $7-14 \%$ at every meteorological station (inshore and continental ones), in the summer period and during the whole year as well. In the months from September to December at inshore stations it

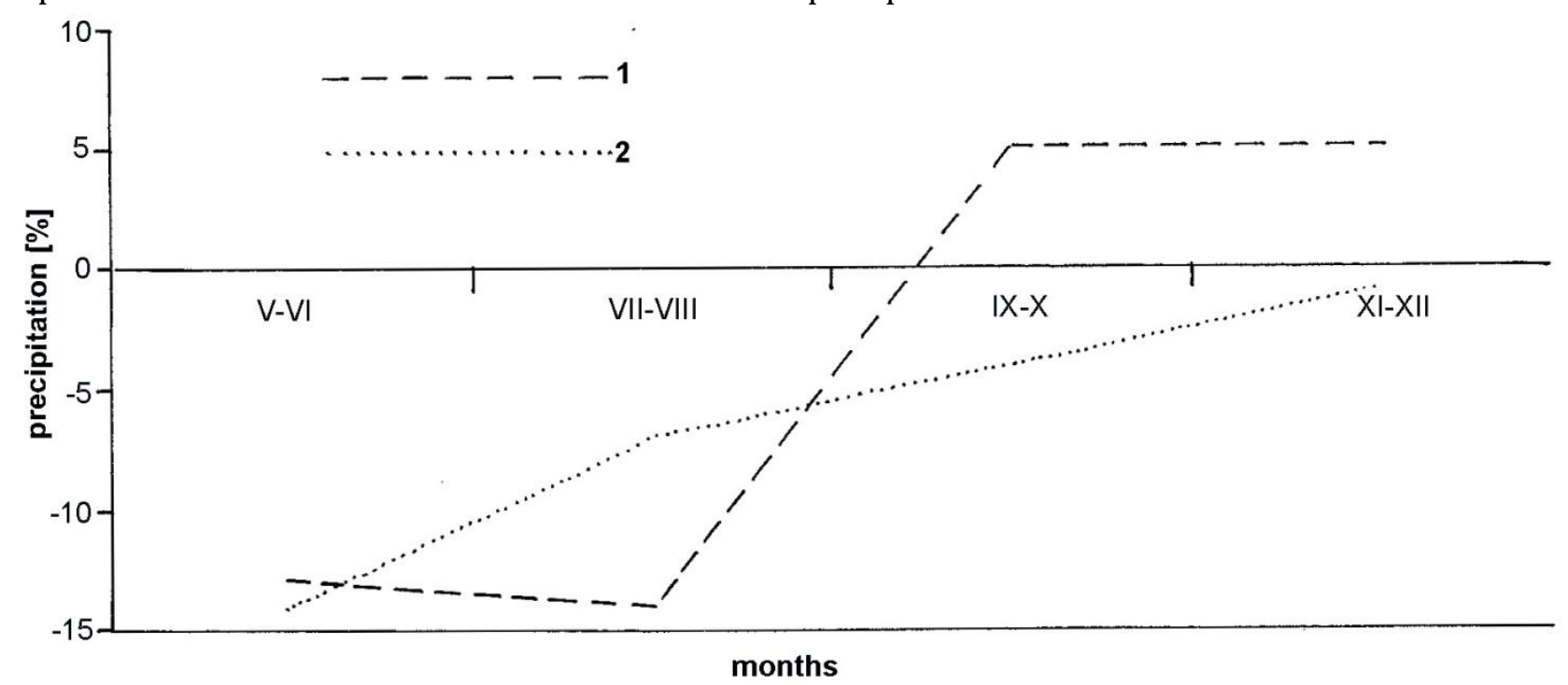

Fig. 3. The monthly precipitation changes (\%) in the region of Ust-Ilimsk reservoir

(after Gustokashina \& Balybina, 2005)

1 - coastal stations; 2 - continental stations increased by $5 \%$, whereas at continental ones - it decreased by $1-4 \%$. After the creation of the reservoir - in the warm period of the year (May August) at the water table and in an area directly adjoining it the precipitation sum decreased. This confirms the results of other investigations on other Russian reservoirs.

We can deal here with the obvious cooling effect of the water mass of the reservoir. In the autumn-winter period the thermal contrast airwater is significant, evaporation from the water surface increases, in connection with this the probability of cloud development and precipitation formation also increases. According to GUSTOKASHINA \& BALYBINA (2005), on the basis of the results obtained by means of the method of spatial differences it is possible to state, that the most distinct changes in the average values of annual precipitation sums occurred at stations located close to the reservoir (directly over it and at a distance of 3-5 km). At larger distances the influence of the reservoir on the amount of precipitation decreases.

\subsection{Cloud cover}

Owing to the increase in the water vapour content of the air over the reservoir surface the regime of cloud cover in seasons of the year without ice also changes. Observations show that during night hours the number of 24 hour periods with small cloud cover increases, whereas during the day the cloud cover over the water surface disperses, but it is formed over shores. It has a connection with ascending air 


\subsection{Fogs}

In the winter period below the dams of the Bratsk and Ust-Ilimsk reservoirs polynya (a place free from ice at the frozen surface) are created. Owing to difference in air and water temperature and also during water falling from dams $100-\mathrm{m}$ high at both reservoirs fogs are created, including the whole area in the neighbourhood of the dam. According to data of the Swedish Meteorological and Hydrological Institute, in the period before and after the creation of an artificial reservoir the number of foggy days in the summer period does not change, whereas in the winter, when polynya exist, the number of days with fogs over reservoirs increases (VASIL'YEV, 1982). According to RAZUVANOV (1970) the creation of the Ust-Ilimsk reservoir, similar to the Bratsk reservoir, caused fogs to be a permanent phenomenon in the autumn period. They include the whole inshore part of water body and spread into the depths for $0.5-1.5 \mathrm{~km}$. Fogs in the shore zone of the Ust-Ilimsk reservoir delay the coming of frosts by 1-2 weeks and decrease their intensity. In connection with the 24 hour amplitudes of temperature the reservoir shores become more gentle, because they react to frequent heat change (TASHLYKOVA, 2007).

\subsection{Winds}

The wind regime on the Ust-Ilimsk water reservoir is diverse because it has a connection with the relief of particular sections of the region and with the geographical location of the reservoir. The direction and velocity of prevailing winds during the whole year depend most of all on the distribution of atmospheric pressure in particular seasons of the year. In the southern part of the reservoir winds from a western direction predominate. Further north the duration and maximum wind velocities increase. Winds from the western, north-western and eastern sectors prevail in the summer: frequent weather changes accompany them - cloud cover, precipitation and gusty winds. In the winter weak winds from the south-west and west predominate. Average annual wind velocity does not exceed 2$2.5 \mathrm{~m} / \mathrm{s}$. In the spring and autumn - owing to the activation of cyclone centres - average monthly wind velocities increase and reach the highest values during a year. In this period the wind velocity over the water table can reach more than $28 \mathrm{~m} / \mathrm{s}$, and the duration of storms amount to more than 50 hours (REPETIN, 1969; BUBLIKOVA \& KOSHINSKIY, 1975). Average monthly wind velocities in the spring and autumn are more than $3.5 \mathrm{~m} / \mathrm{s}$.
According to data from the Bratsk Hydrometeorological Observatory, winds of velocity of $30 \mathrm{~m} / \mathrm{s}$ blow over the reservoir only from a north-western direction. Maximum wind velocities from the remaining directions do not exceed $25 \mathrm{~m} / \mathrm{s}$. The frequency of occurrence of winds over $15 \mathrm{~m} / \mathrm{s}$ is slight - they are most often observed in September and October, June and July are more calm. In August winds appear more often than in June-July, but their duration is short. Winds of velocities of 5 and $8 \mathrm{~m} / \mathrm{s}$ occur rather frequently (OvCHINNIKOV, 2003).

\section{Discussion}

To evaluate the influence of the Ust-Ilimsk reservoir on the inshore area, GUSTOKASHINA \& BALYBINA (2005) calculated the Gorchinskiy's index of continentality. This coefficient in the investigated area decreased on average by $4-5 \%$. The results of this suggest that the climate of inshore areas became milder during the existence of the reservoir. The largest changes in continentality index were observed at the Zheleznogorsk meteorological station on the Ust-Ilimsk reservoir $(-10.4 \%)$. One should emphasize that seasonal and annual fluctuations of precipitation sums, air temperatures and climate continentality cannot be connected exclusively with the influence of the reservoir, because they also reflect the regional character of the climate.

On the basis of the investigations on local climate over other water reservoirs it was stated that the cooling influence of reservoirs spreads to a smaller distance, whereas warming - to a larger one. The width of the zone of influence for the particular shore is also not the same, because it depends on the wind direction. The most extensive zone of influence is at open shallow shores, but at distances of more than $1 \mathrm{~km}$ from the water level the degree of reservoir influence decreases by 50\% (VENDROV ET AL., 1968).

According RASTORGUEV \& ROSHCHINA (1987), the influence of hydrostation reservoirs on the local climate is manifested mainly in the ice-free period and extends to distances from several tens of meters to several tens of kilometers from the waterline inland in the upper pools and distances of up to several hundred kilometers downstream in a comparatively narrow riparian belt. For example, the effect of the reservoir at the Bukhtarma hydrostation extends more than $1500 \mathrm{~km}$ down the Irtysh river. The width of the zone of influence on local climate decreases from the north to the south. For example, the influence of the Rybinsk reservoir reaches 10-12 km (constant 
effect) and about $30 \mathrm{~km}$ (occasional effect), the influence of the Tsimlyansk reservoir respectively reaches several hundred meters and about $1-2 \mathrm{~km}$.

The differences in the results of average temperatures between the water surface and air, in deep northern reservoirs in the period May July are lower than the 24 hour average mean temperature at shores by $0.2-0.9^{\circ} \mathrm{C}$. Their warming influence becomes perceptible from August, when the difference between the average 24 hour temperature of the shore and deeply located areas reaches $3^{\circ} \mathrm{C}$. The stated features of heat regime of shores of artificial water reservoirs and lakes manifest themselves in the strongest way in a 200-400 m wide zone (D'YAKONOV \& RETEYUM, 1970). The building of Ivankovo reservoir (in 1937) of $327 \mathrm{~km}^{2}$ in area and capacity of $1.12 \mathrm{~km}^{3}$ caused an increase in the average annual air temperature by $0.3-0.4^{\circ} \mathrm{C}$, and the distinct zone of influence on the climate amounts to $400-900 \mathrm{~m}$ (ZHIRKEVICH, 1992). The influence of reservoirs on changes in humidity and air temperatures quickly decreases together with the increase in distance from it. For relatively large water reservoirs the rate of decreasing influence is proportional to the logarithm of the distance from shoreline (TIMOFEYEV, 1963).

Building artificial water reservoirs with considerable areas of surface water leads to an increase in evaporation, which in turn causes a change in the relative humidity of the air in adjacent areas. The difference of average monthly values of relative humidity between the reservoir and the shore zone amounts to about 15-18\% (VodoKHRANILISHCHA, 1986). The average monthly values of water vapour pressure included in the air over the reservoir surface are $0.5-3$ milibars higher on average than at the shore. In the course of 24 hours the water vapour pressure, which is most distinct in the summer, at the shore zone of Bratsk and Krasnoyarsk reservoirs, located in the same climatic zone as Ust-Ilimsk reservoir, has one noticeable maximum (5-7 p.m.) and one minimum (2-3 a.m.). Over the water surface of the above-mentioned reservoirs these phenomena occur with a 1-2-hour delay. The precipitation sum at shores of large reservoirs is $10-20 \%$ lower than within the land. Long-lasting observations on the Volgograd reservoir indicate that the precipitation sum in the period from June to October over the water surface is $10-20 \%$ lower in comparison to the shore zone.

The relief has considerable influence on the shaping of the microclimate of water reservoirs - it can play a larger role than absolute heights, creating conditions for specific (24 hours' and seasonal) air circulation over the water surface and adjacent areas. In the case of the Ust-Ilimsk reservoir the influence of the relief on microclimate is reflected in narrowing zones of steep exposed slopes.

To investigate shaping of meteorological conditions at the shore of Bratsk reservoir expeditions were conducted by Razuvanov (1970). Their results can be applied to locations further north than the Ust-Ilimsk reservoir. The main influence of the water reservoir on the microclimate is reflected in cloud cover, surface albedo and fogs.

Results of investigations by DEGU ET AL. (2011) conducted over 92 large water reservoirs in the USA, indicate, that their influence is the largest in Mediterranean and semi-desert climates, whereas it is lowest in humid climates. CHANGNON (1966) proved the influence of Lake Michigan on the formation of storms, especially in the summer and autumn. The influence of the Great Lakes on local climate was also described by LOFGREN \& ZHU (1999).

\section{Conclusions}

The Ust-Ilimsk water reservoir distinctly influences the local climate of adjacent areas. These are connected most of all with an increase in total radiation and a change in radiation balance of the reservoir and a larger heat capacity of the water mass in comparison to the land. As data from meteorological stations indicate, the climate in the neighbourhood of the analysed water reservoir gains many new features and generally becomes milder. The average annual increase in air temperatures over the reservoir shores reached $1.3^{\circ} \mathrm{C}$, whereas within the land - only $0.4^{\circ} \mathrm{C}$. At every meteorological station (inshore and continental) in the summer and within the whole year as well, the average annual precipitation sum decreases by $7-14 \%$. In the winter, when połynya exist, over the reservoir the number of days with fogs increases. Moreover, fogs in the shore zone of Ust-Ilimsk reservoir delay the coming of frosts by 1-2 weeks.

\section{References}

Atlas Irkutskoy oblasti. Irkutsk, 1997.

Atlas Irkutskoy oblasti. Moskva, 1962.

Avakyan A.B., Saltankin V.P., Sharapov V.A. 1987. Vodokhranilishcha. M.: Mysl'.

Borushko I.S. 1965. Effect of reservoirs on air temperature and humidity of a coast. Leningrad Gl. Geofiz. Observ. Tr., 182: 38-49.

Bublikova YU.I., Koshinskiy S.D. 1975. Tipy poley vetra nad Bratskim vodokhranilishchem i ikh statisticheskiye kharakteristiki. Gidrometeorologicheskiy rezhim vodokhranilishch $i$ krupnykh ozer Sibiri. Vyp.18., M.: Gidrometeoizdat. 
Changnon S.A. 1966. Effect of lake Michigan on severe weather. Proc. of the 9th Conf. on Great Lakes Research, Great Lakes Dinision Michigan Publ., 15: 220-234.

Degu A.M., Hossain F., Niyogi D., Pielke R.A. Sr., Shepherd M., Voisin N., Chronis T. 2011. The influence of large dams on surrounding climate and precipitation patterns. Geoph. Research Letters, 38, 4: L04405, doi:10.1029/2010GL046482.

D'yakonov K.N., Reteyum A.YU. 1970. Prognozirovaniye mestnogo klimata $v$ rayone Pecherskogo vodokhranilishcha. Vliyaniye vodokhranilishch lesnoy zony na prilegayushchiye territorii. M.: Nauka.

Gustokashina N.N., Balybina A.S. 2005. Izmeneniye prirodnoklimaticheskikh kharakteristik territorii, prilegayushchey $\mathrm{k}$ vodokhranilishcham Angarskogo kaskada GES. Geogr. prirodnyye resursy, 4: 93-100.

Hossain F., Jeyachandran I., Pielke R.A. Sr. 2010. Dam safety effects due to human alteration of extreme precipitation. Water Resour. Res., 46, W03301, doi:10.1029/2009WR007704.

Lewińska J. 1974. Wpływ karpackich zbiorników wodnych na klimat lokalny na przykładzie kaskady górnego Sanu. Prace Inst. Meteorol. i Gosp. Wodnej, 3.

Lofgren B.M., Zhu Y. 1999. Seasonal climatology of surface energy fluxes on the Great Lakes. Great Lakes Environ. Research Laboratory, Glerl Publ.

Magomedov M.M. 2003. Priroda Ust-Ilimskogo rayona. Irkutsk - Ust'-Ilimsk; Izd-vo IG SO RAN.

Małecki Z. 2009. Wpływ zbiornika zaporowego Pokrzywnica na mikroklimat w zlewni Pokrzywnicy, prawobrzeżnym dopływie Prosny. Ochrona Środ. i Zasobów Naturalnych, 39: 103-114.

Marzec Z. 1971. Wpływ zbiornika rożnowskiego na klimat lokalny. Prace Państ. Inst. Hydrol.-Meteorol., 101.

Meijninger W.M.L., de Bruin H.A.R.. 2000. The sensible heat fluxes over irrigated areas in westarn Turkey determined with a large aperture scintillometer. J. Hydrology, 229: 42-49.

Miczyński J., Zuśka Z., Jabłońska-Korta U., Jurkiewicz T. 2010. Próba oceny zmiany klimatu lokalnego w wyniku oddziaływania zbiornika wodnego na przykładzie występowania mgieł w Czorsztynie. Monografie Pienińskie, 2: 123-129.

Obrębska-Starklowa B., Grzyborowska A. 1995. Sezonowe zróżnicowanie dobowego przebiegu temperatury powietrza w rejonie dobczyckiego zbiornika wodnego. Probl. Zagosp. Ziem Górskich, 38.
Ovchinnikov G.I. 2003. Dinamika beregovoy zony Angarskikh vodokhranilishch. Dis. d-ra geogr. nauk. - Irkutsk.

Rastorguev V.J., Roshchina I.M. 1987. Consideration of changes in the local climate in the region of the reservoir and lower pool of hydroelectric stations. Gidrotekhnicheskoe Stroitel'stvo, 10: 16-17.

Razuvanov V.G. 1970. Formirovaniye meteorologicheskikh usloviy nad poberezh'yem Bratskogo vodokhranilishcha. Trudy Limnol. Instituta, T. 15: 84-119.

Repetin L.N. 1969. Bratskoye vodokhranilishche. Sbornik rabot Bratskoy GMO: 6-19.

Rodhe B. 1968. Studies on the effect of lake regulation on local climate. Swedish Meteorol. and Hydrol. Inst. Medd., Ser. B, 28: 61-77.

Tashlykova T.A. 2006. Klimaticheskiye usloviya kak faktor formirovaniya urovennogo rezhima Ust-Ilimskogo vodokhranilishcha. Geologiya, poiski i razvedka poleznykh iskopayemykh i metody geologicheskikh issledovaniy. $S b$. izbr. tr. nauch.-tekhn. konf. fak-ta geologii, geoinformatiki $i$ geoekologii. Vyp. 6. Irkutsk: Izd-vo IrGTU: 97-100.

Tashlykova T.A. 2007. Wpływ Zbiornika Ust-Ilimskiego na mikroklimat przyległych obszarów. Kształt. środ. geogr. $i$ ochr. przyr. na obsz. uprzem. i zurb., 38: 55-63.

Timofeyev M.P. 1963. Meteorologicheskiy rezhim vodoyemov. L.: Gidrometeoizdat.

Ust'-Ilimskoye vodokhranilishche. Novosibirsk: Nauka, 1975.

Vasil'yev YU.S. 1982. Vliyaniye plotin $i$ vodokhranilishch na okruzhayushchuyu sredu. - M.: Energoatomizdat.

Vendrov S.L., Avakyan A.B., D'yakonov K.N., Reteyum A.YU. 1968. Rol' vodokhranilishch $v$ izmenenii prirodnykh usloviy. M.: Znaniye.

Viculina Z.A., Seljuk E.M. 1966. Study of hydrometeorological regime of large reservoirs of the USSR. Symp. of Garda, Int. Ass. Sci. Hydrol. Publ., 70: 132-139.

Vodokhranilishcha i ikh vozdeystviye na okruzhayushchuyu sredu. M: Nauka, 1986: 126-128.

Wang W., Liu W., Ma X. 2012. Analysis for influence upon local climate factor of reservoir area of hydropower station after water storage. App. Mechanics and Materials, v. 212-213: 245-252.

Zhirkevich A.N. 1992. Effect of reservoirs of the Zagorsk pumped-storage station on local climatic changes. Gidrotekhnicheskoe Stroitel'stvo, 9: 25-27. 